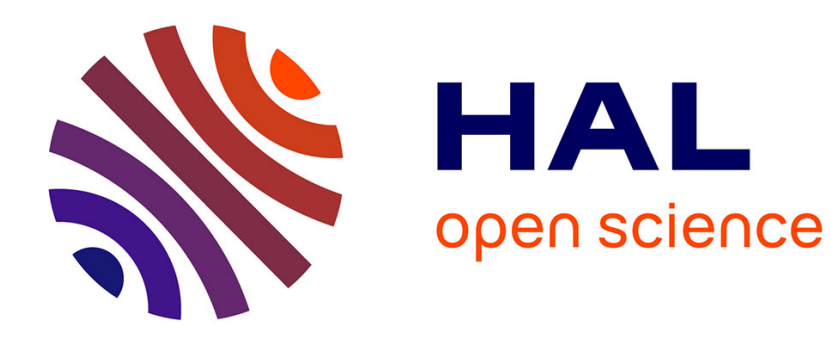

\title{
K. Cairns and J. Johnston, 2015, Food and Femininity Julie M. Parsons
}

\section{To cite this version:}

Julie M. Parsons. K. Cairns and J. Johnston, 2015, Food and Femininity: London, Bloomsbury, 240 p.. Review of Agricultural, Food and Environmental Studies, 2016, 97 (4), pp.273-275. 10.1007/s41130016-0030-5 . hal-03114839

\section{HAL Id: hal-03114839 \\ https://hal.science/hal-03114839}

Submitted on 19 Jan 2021

HAL is a multi-disciplinary open access archive for the deposit and dissemination of scientific research documents, whether they are published or not. The documents may come from teaching and research institutions in France or abroad, or from public or private research centers.
L'archive ouverte pluridisciplinaire HAL, est destinée au dépôt et à la diffusion de documents scientifiques de niveau recherche, publiés ou non, émanant des établissements d'enseignement et de recherche français ou étrangers, des laboratoires publics ou privés. 


\title{
K. Cairns and J. Johnston, 2015, Food and Femininity
}

\author{
London, Bloomsbury, 240 p.
}

\author{
Julie M. Parsons ${ }^{1}$
}

Published online: 8 December 2016

(C) INRA and Springer-Verlag France 2016

In Food and Femininity, Kate Cairns and Josée Johnston provide a timely contribution to the field of food studies with their focus on the performance of contemporary food femininities amongst women and men from Canada and North America. They did not originally set out to investigate femininity but were instead engaged in research that focused on consumer food choice. This research began with a series of 20 focus groups that included 89 participants (69 women and 20 men) and examined how Canadian and American consumers negotiated food decisions in their everyday lives. It was following on from these that they decided to "probe more deeply into women's personal food narratives" and carried out 40 interviews with women (who had not previously participated in the focus groups), eleven women specifically targeted because of their roles as Toronto-based food activists in keeping with their unwavering commitment to food justice and the ethics of consumption. Following analysis of these texts alongside a discourse analysis of food blogs and magazines, they organize their book around important themes for middle class female food consumers, especially those in neo-liberal highly Westernized societies, notably five key sites/chapters: shopping (3), mothering/maternal foodwork (4), health and embodiment/the 'do-diet' (5), politics (6), and pleasure (7).

These "findings" chapters are bookended with a concluding chapter and two introductory chapters that position the book. Firstly, in "caring about food", Cairns and Johnston following DeVault (1991) ask how food and femininity are connected today. Secondly, they develop what they refer to

Julie M. Parsons

J.M.Parsons@plymouth.ac.uk

1 University of Plymouth, Room 209, 9 Portland Villas, Drake Circus, Plymouth, Devon PL4 8AA, UK as a conceptual toolkit. Drawing on feminist theories of embodiment, they identify how food continues to be a key means of "doing" and/or performing gender. They argue that contemporary femininity is constituted through "multiplicity", with women engaged in negotiating "post-feminist ideals of consumer choice, pleasure, and individual empowerment through food". Cairns and Johnston's conceptualization of "calibration" is particularly noteworthy as it highlights how women position themselves as reasonable, informed, and moderate when negotiating tensions between the politics and pleasures of consumption in neo-liberal societies. They refer to women continually calibrating positions to avoid pathologized performances of femininity such as "making healthy" food choices without becoming a "food fanatic" (p. 92) or being "committed to the politics of food" without being dogmatic, whereby "politically minded participants distanced themselves from an uncaring, unethical approach to food, [but] also rejected an overly perfect or righteous model" (p. 118). This theory of calibration runs throughout the book, and the authors contend that their participants engage in an "extensive" and "active" calibration (negotiation of these boundaries), while simultaneously making it appear effortless. These tensions, or binaries are reminiscent of Warde's (1997) four antinomies of taste used by advertisers in food marketing, notably (1) "novelty and tradition", (2) "health and indulgence", (3) "economy and extravagance", and (4) "convenience and care".

In the first of the five "findings" chapters, Cairns and Johnston examine food shopping, which continues to be a particularly gendered activity. They make use of Bourdieu's (1984) conceptualization of habitus to explore how these gendered experiences intersect with issues of race and class. They distinguish between "privileged women, able to invest in hegemonic consumer femininities by virtue of their cultural and economic resources" with those shopping for food on limited budgets. They clearly identify the boundaries here between 
what might be considered a "respectable middle class femininity and a pathologized working class one", particularly in terms of the "disgust" expressed by some in relation to discount stores. Indeed, it is in the arena of food shopping that Cairns and Johnston make the most of how gender and class/ race intersect. The classed dimension to everyday foodways (ways of doing food) (see Parsons 2015a) is less explicit throughout the rest of the book, although there is always a laudable nod towards the need for some kind of food justice.

The focus of the second of the findings chapters is on maternal foodwork, although only a third of the participants from the focus groups and interviews can be identified as parents. Cairns and Johnston highlight how in a contemporary foodscape discourses on food risk and issues of ethical consumption, means that mothers in their study, continue to calibrate the boundaries of "intensive mothering" (Hays 1996), as well as acting as guardians of health for the family. Alternatively, one might consider how mothers calibrate what Warde (1997) might refer to as a care and convenience antinomy, with the use of "convenience" foods associated with "lack" of care or poor mothering. Indeed, the association between "good" mothering and preparing "healthy" homecooked meals from scratch is discussed more fully elsewhere and can be directly related to issues of class/cultural norms and values (Parsons 2014, 2016). In Cairns and Johnston's study, the focus is on raising a "pure", "self-regulating", "organic child" and the need for middle class mothers in their study to calibrate a position between the over protective intensive mother and one who does not care. They identify how a "good mother" provides "healthy meals, socializes neo-liberal individual tastes, and protects children from food system risks". Indeed the interweaving of the personal with the political is ever present. The focus on ethical food politics reflects Cairns and Johnston's particular interests in this area (Cairns et al. 2010; Johnston and Baumann 2010).

In the "do-diet" chapter, the women in Cairns and Johnston's study carefully calibrate a position between health and indulgence, with a gendered pressure to perform "proper" healthy eating. They introduce the notion of the "do-diet", which they explain has developed in response to middle class women eschewing explicit "dieting" (excessive food restriction) in favor of healthy eating. Again, they contend that women have to engage in extensive calibration to avoid being considered "pathological" or fanatic in control but not denying pleasure. They argue that this "do-diet" places women in a "double bind, as those who openly restrict their diet are viewed as disempowered"; on the other hand "those who do not monitor and control food consumption may fail to embody the healthy (read thin) ideal". Indeed, they highlight how the focus on "healthy" eating has not released women from the tyranny of slenderness (Chernin 1981; LeBesco 2001) as an enduring cultural symbol of contemporary femininity. This is what Bourdieu (1984:175) refers to as an "ethic of sobriety for the sake of slimness". Further, Cairns and Johnston rightly emphasize how the "do-diet" despite its "anti-diet message reproduces and legitimizes fat phobia and undermines what might be considered a feminist aim for social justice for all women regardless of body size" (p. 107).

The book is especially strong when it concerns issues of particular interest to Cairns and Johnston; for example, their chapters on food politics and pleasure (foodies) are reminiscent of their previous work (Cairns et al. 2010; Johnston and Baumann 2010). Again, when women in their study embrace the care-work of ethical consumption, these performances require active calibration, even though "they are committed to the politics of food, they are careful not to be dogmatic in their approach." Cairns and Johnston argue that "feminine subjects become pathological if their political commitment inconveniences, overshadows or marginalizes their immediate care relationships." They explain how vegetarian participants like the mothers who "hide" vegetables in their children's meals, will eat a potato cooked in a pan with chicken, or prepare delicious "vegetarian" meals all week, in order to not appear "extreme" or "fanatical". This is certainly something that does not usually concern men when examining their approach to food politics or pleasure (see Parsons 2015b). Similarly "foodie femininities challenge other longstanding feminine goals of health promotion, ethical responsibility, and care for others - goals that are deeply woven within cultural renderings of food and femininity". Here, "everyday cooking" is a taken-for-granted component of women's daily everyday foodwork, while leisure cooking continues to be coded as male or certainly only available to those "free" from ordinary (mundane) domestic responsibilities (Parsons 2015a, 2015b).

Cairns and Johnston conclude by calling for a culinary reskilling (of both men and women) and the development of a feminist food politics that avoids sectarianism. However, while they "acknowledge that meeting (or at least approximating) contemporary standards of normative femininity requires tremendous attention to food", they believe that "caring about food" is rich in political possibilities for social justice. This book clearly demonstrates the complexities of contemporary food femininities, how women negotiate the fine line between hegemonic and pathological performances of femininities, as well as post-feminist ideals concerned with consumer choice, pleasure, and individual empowerment through food. Further, Cairns and Johnston make a strong case for the possibilities of a feminist food politics to "revitalize collective movements" and expand the horizons of a gendered social justice. It is therefore also particularly relevant to those interested in the ethics of consumption and not just food scholars.

Overall, the book provides a clear insight into the tensions inherent in the performance of "appropriate" everyday foodways for middle class women participants in contemporary North America and Canada, who engage in what might be considered forms of "culinary capital" (Naccarato and 
LeBesco 2012). Cairns and Johnston's notion of calibration is supposed to be effortless, yet is clearly emotional work that requires time and money (i.e. an investment of economic capital). As noted previously, there are some references to the pressures of economic disadvantage on calibrating food femininities; however, there could certainly have been a greater emphasis placed on the fact that "calibration" is a privilege for those who do not have to worry about where the next meal is coming from. Indeed, performances of femininities are influenced by intersectionalities of gender with class, race, and age while there are some fleeting references to this, the heart of the book emphasizes the difficulties of calibrating food femininities for middle class White women and this could have been more clearly highlighted as its focus from the beginning.

\section{References}

Bourdieu P (1984) Distinction, a social critique of the judgement of taste. Routledge, London $613 \mathrm{p}$

Cairns K, Johnston J, Baumann S (2010) Caring about food: doing gender in the foodie kitchen. Gend Soc 24(5):591-615
Chernin K (1981) The Obsession: Reflections on The Tyranny of Slenderness. Harper and Row, New York $206 \mathrm{p}$

DeVault ML (1991) Feeding the family. The social organization of caring as gendered work. University of Chicago Press, Chicago $284 \mathrm{p}$

Hays S (1996) The cultural contradictions of motherhood. Yale University Press, New Haven 252 p

Johnston J, Baumann S (2010) Foodies, democracy and distinction in the gourmet foodscape. Routledge, London $260 \mathrm{p}$

LeBesco K (2001) Queering fat bodies/politics. In: Braziel JE, LeBesco $\mathrm{K}$ (eds) Bodies out of bounds, fatness and transgression. University of California Press, London, pp. 74-90

Naccarato P, LeBesco K (2012) Culinary capital. Berg, New York 160 p

Parsons JM (2014) Cheese and chips out of styrofoam containers': an exploration of taste and cultural symbols of appropriate family foodways. J Media Cult 17(1). http://journal.media-culture.org.au/index

Parsons JM (2015a) Gender, class and food: families, bodies and health. Palgrave MacMillan, Basingstoke $195 \mathrm{p}$

Parsons JM (2015b) The joy of food play - an exploration of the continued intersectionalities of gender and class in men's auto/ biographical accounts of everyday foodways. Women, Gender and Research 3-4:35-48

Parsons JM (2016) When convenience is inconvenient, 'healthy' family foodways and the persistent intersectionalities of gender and class. J Gend Stud 25(4):282-397 http://www.tandfonline. $\mathrm{com} / \mathrm{doi} / \mathrm{abs} / 10.1080 / 09589236.2014 .987656$ ?journalCode=cjgs20

Warde A (1997) Consumption. Food and Taste, London, Sage 240 p 